\title{
Ion channels in liver diseases and hepatocellular carcinoma: potential tools for diagnosis, prognosis, and therapy
}

\author{
María de Guadalupe Chávez-López ${ }^{1}$, Andrea Cruz-Díaz², Karla Nicol Tlapalcoyoa-Apanco², Julio Isael \\ Pérez-Carreón ${ }^{3}$, Javier Camacho ${ }^{1}$ \\ 'Department of Pharmacology, Centro de Investigación y de Estudios Avanzados del Instituto Politécnico Nacional, Mexico City \\ 07360, Mexico. \\ ${ }^{2}$ Escuela de Ciencias de la Salud, Universidad del Valle de México, Mexico City 04910, Mexico. \\ ${ }^{3}$ Instituto Nacional de Medicina Genómica, Mexico City 14610, Mexico.
}

Correspondence to: Dr. Javier Camacho, Department of Pharmacology, Centro de Investigación y de Estudios Avanzados del Instituto Politécnico Nacional, Avenida Instituto Politécnico Nacional 2508, Mexico City 07360, Mexico.

E-mail: fcamacho@cinvestav.mx

\begin{abstract}
How to cite this article: Chávez-López MG, Cruz-Díaz A, Tlapalcoyoa-Apanco KN, Pérez-Carreón Jl, Camacho J. Ion channels in liver diseases and hepatocellular carcinoma: potential tools for diagnosis, prognosis, and therapy. Hepatoma Res 2020;6:14. http://dx.doi.org/10.20517/2394-5079.2019.023
\end{abstract}

Received: 25 Oct 2019 First Decision: 22 Nov 2019 Revised: 15 Mar 2020 Accepted: 23 Mar 2020 Published: 10 Apr 2020

Science Editor: Dalbir Singh Sandhu Copy Editor: Jing-Wen Zhang Production Editor: Jing Yu

\begin{abstract}
Cancer is a major cause of death worldwide. Hepatocellular carcinoma (HCC) is one of the malignancies with the highest mortality-to-incidence ratio (>0.9), and in some countries this value is up to 1 . Unfortunately, many patients are diagnosed at advanced stages of the disease. Therefore, HCC early markers, as well as novel therapeutic approaches, are urgently needed. HCC is the main type of liver cancer and it is associated with different factors including alcohol use, viral infections, and fatty liver disease. A significant percentage of HCC patients previously had liver cirrhosis. Several ion channels have been proposed as novel potential markers and therapeutic targets for diverse cancers including HCC. Here, we review most of the findings associating ion channel expression with $\mathrm{HCC}$ and its etiological factors, as well as some possible pro-tumorigenic mechanisms of action for ion channels in HCC. Novel therapies for HCC treatment and prevention are also discussed. Ion channel targeting offers a plethora of opportunities for HCC prevention, early diagnosis, and therapy that may help to reduce the extremely high mortality-to-incidence ratio of this malignancy.
\end{abstract}

Keywords: Ion channels, hepatocellular carcinoma, hepatitis virus, cirrhosis, liver disease, alcohol

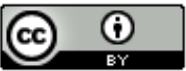

(C) The Author(s) 2020. Open Access This article is licensed under a Creative Commons Attribution 4.0 International License (https://creativecommons.org/licenses/by/4.0/), which permits unrestricted use, sharing, adaptation, distribution and reproduction in any medium or format, for any purpose, even commercially, as long as you give appropriate credit to the original author(s) and the source, provide a link to the Creative Commons license, and indicate if changes were made.

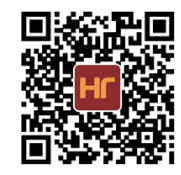




\section{INTRODUCTION}

Cancer is a leading cause of death worldwide, despite the existence of hundreds of clinical trials testing novel therapies ${ }^{[1,2]}$. There are several types of liver cancer including hepatoblastoma, cholangiocarcinoma, and angiosarcoma, but hepatocellular carcinoma (HCC) accounts for up to $90 \%$ of primary liver cancers ${ }^{[3-7]}$. Liver cancer is one of the malignancies with the worst prognosis, representing the second leading cause of cancer-related deaths in the world ${ }^{[3-5]}$.

The liver plays a central role in regulating whole-body carbohydrate, lipid, and protein homeostasis, as well as playing additional very important physiological roles including the synthesis and transport of bile acids and the detoxification of endogenous and exogenous metabolites ${ }^{[6,8]}$. This very important organ is exposed to several factors including infections by hepatitis viruses B and $\mathrm{C}$, alcohol use, aflatoxin B1, and fatty diet. Several of these factors lead to liver cirrhosis, which is the major HCC-associated risk factor ${ }^{[6,9-11]}$. In fact, a significant percentage ( $>80 \%$ ) of HCC patients previously had liver cirrhosis. Unfortunately, HCC is rarely detected at early stages, and is usually fatal within a few months of diagnosis. The percentage of mortality-to incidence ratio of liver cancer is very high; it is more than $90 \%$ globally, reaching up to $100 \%$ in some countries ${ }^{[1]}$. Therefore, novel early HCC markers and therapeutic strategies are urgently needed. In this regard, ion channels have gained great interest in oncology, as novel tools for both diagnosis and treatment ${ }^{[5]}$. Here, we summarize most of the research associating ion channels with HCC. We also discuss the potential tumorigenic mechanisms of action of ion channels in HCC, as well as ion channel-based therapies for HCC prevention and treatment. The growing research field of ion channels in cancer may lead to reduce the incidence and mortality of liver cancer.

\section{ION CHANNELS AND CANCER}

Ionic channels are pore-forming membrane proteins allowing ion flux across membranes, including the plasma membrane and those from of intracellular organelles. In most cases, these proteins selectively transport specific ions and the vast majority need special stimulus to be activated ${ }^{[12]}$. These gating stimuli include changes in membrane potential (voltage-gated ion channels), different ligands such as hormones or neurotransmitters, temperature, mechanical forces, etc. Thus, the role of ion channels in human physiology comprises very important phenomena such as neural transmission, cardiac function, hormone release, sensory physiology, etc. Accordingly, many channelopathies exist including epilepsy, cardiac arrhythmias, renal diseases, blindness, skeletal muscle disorders, etc $^{[12]}$. Cancer is a multi-factorial disease characterized by an increased cell proliferation rate; ion channels are essential for regulation of proliferation and are also involved in many relevant processes occurring during carcinogenesis, which convert these proteins into potential cancer diagnostic tools and therapeutic targets.

\section{Ion channels associated with cancer}

The roles that ion channels have during carcinogenesis depend on the step of tumor development and the tissue type ${ }^{[13,14]}$.

Calcium channels participate in pivotal functions in the body such as regulation of blood pressure, muscle contraction, secretion, metabolism, excitability, and cell proliferation ${ }^{[15]}$. These channels are important in the cell cycle, especially to enter and accomplish the $S$ and $M$ phase $e^{[14-18]}$; thus, their participation in cancer cell proliferation is very relevant ${ }^{[14,16,17]}$. In addition, because these ions are very important for cell migration, they also play a very important role in cancer cell migration and metastasis ${ }^{[16-19]}$.

Potassium channels play crucial roles in every cell type and in all species. Based on their structure and function, they are categorized into three major classes: the voltage-gated (Kv), inwardly rectifying (Kir), and tandem pore domain $(\mathrm{K} 2 \mathrm{P})$ channels. Furthermore, various messengers can stimulate the ligand- 
gated (Kligand) channels ${ }^{[20]}$. Membrane hyperpolarization due to potassium channel activity is needed for cell cycle progression from G1 to S phase. Potassium flux is also very important for apoptosis, cell volume regulation, and cytokine release. Therefore, even though the precise molecular mechanism of $\mathrm{K}^{+}$channel participation in cancer remains elusive, these channels have a significant role in the cell proliferation, migration, and angiogenesis of a variety of carcinoma cells $s^{[14,21,22]}$.

Different subtypes of voltage-gated sodium channels (VGSC) are differentially expressed throughout the body, and they have essential roles in the generation and propagation of action potentials in electrically excitable cells such as neurons and cardiac and skeletal muscle ${ }^{[23]}$. Several carcinoma cells express VGSC $^{[14,24,25]}$. Interestingly, these channels are active in metastatic cells ${ }^{[25]}$. Accordingly, sodium currents through VGSC enhance migration, invasion, and metastasis in vivo ${ }^{[26]}$.

Chloride channels are involved in many biological functions such as epithelial fluid secretion, cell-volume regulation, modulation of excitability, smooth-muscle relaxation, and $\mathrm{pH}$ regulation. Cystic fibrosis is a disease where the relevance of alterations in chloride flux has been shown ${ }^{[27]} \cdot \mathrm{Cl}^{-}$channels are involved in apoptosis, and in cancer cells these proteins promote proliferation, migration, and invasion ${ }^{[14,21,28-30]}$. These channels are over-expressed in many cancer tissues including liver compared to noncancerous tissues, and are significantly associated with tumor size, metastasis, and poor prognosis ${ }^{[31]}$.

Before going into the details of ion channels in liver diseases leading to HCC, we first review some of the channels for which expression has been reported in the normal liver.

\section{ION CHANNELS IN HEALTHY LIVER}

The importance of ion channels in different functions of the normal healthy liver has been reported by several studies. Water crosses the plasma membrane either directly through the lipid bilayer or via protein water channels [aquaporins (AQPs)] ${ }^{[32]}$. The liver expresses at least six AQPs (AQP1, -3, -7, -8, -9, and -11). Immunohistochemical studies showed the expression of AQPs in different hepatic cell types including cholangiocytes (AQP1 and -7), endothelial cells (AQP1), Kupffer cells (AQP3), and hepatocytes, (AQP7, -8 , and -9$)^{[3,34]}$. AQP8 and -9 are relevant for bile synthesis regulation, secretion, and modification ${ }^{[33]}$. Additionally, AQP9 functions as a glycerol channel in the liver ${ }^{[35]}$.

The ATP-sensitive potassium channel $\left(\mathrm{K}_{\mathrm{ATP}}\right)$ is composed of two types of subunits, namely an inwardly rectifying $\mathrm{K}^{+}$channel (Kir6.x) and a sulfonylurea receptor. Kir6.x subunits form the pore, while sulfonylurea receptor subunits have regulatory activity. Depending on its localization at the plasma membrane or in organelles, these channels are classified as sarcolemmal ("sarcK $\mathrm{ATP}_{\text {ATP }}$ ), mitochondrial ("mitoK $\mathrm{ATP}_{\text {"), }}$ or nuclear ("nucK $\mathrm{ATP}_{\text {") }}$ channels ${ }^{[36,37]}$. Interestingly, $\mathrm{K}_{\mathrm{ATP}}$ channel opening has been shown to alleviate liver injury by preventing inflammation and increasing the liver tolerance to ischemia/reperfusion injury ${ }^{[38,39]}$. Besides, DNA synthesis demonstrated that these channels play significant roles in liver growth control ${ }^{[37]}$.

Nucleotides act as extracellular signaling molecules via purinergic receptors. These receptors are separated into seven $\mathrm{P} 2 \mathrm{X}$ ionotropic receptors and eight $\mathrm{P}_{2} \mathrm{Y}$ G protein-coupled receptors ${ }^{[40,41]}$. For instance, the $\mathrm{P} 2 \mathrm{X} 4$ receptor is the dominant $\mathrm{P} 2 \mathrm{X}$ isoform expressed in cholangiocytes in the liver ${ }^{[42,43]}$. ATP is released by hepatocytes, and it regulates hepatocyte glycogen metabolism, cell volume, bile formation, and other cell functions. When activated by ATP, P2X receptors function as cation-permeable channels that allow the influx of sodium and calcium ions ${ }^{[42,43]}$. Interestingly the expression of $\mathrm{P} 2 \mathrm{X} 7$ receptors is decreased in HCC Huh-7 cells ${ }^{[43]}$.

Acid sensing ion channels (ASICs) are $\mathrm{H}^{+}$channels that mediate tumor cell migration and invasion ${ }^{[44]}$, and store-operated calcium entry (SOCE) controls HCC cell proliferation and migration ${ }^{[45]}$. T-type $\mathrm{Ca}^{2+}$ 
channels participate in modulating the proliferation of some HCC cells ${ }^{[46]}$. Because the expression levels of these channels (ASICs, SOCE, and T-type) ${ }^{[44,45]}$ are increased in HCC in comparison with the normal liver, they may be used as markers of the disease.

In the following, we describe several findings associating ion channels with HCC, beginning with some liver diseases representing important HCC etiological factors.

\section{ION CHANNELS IN LIVER DISEASES}

Several liver diseases have been identified as HCC etiological factors, and many ion channels have been found to have a role in liver diseases. Table 1 summarizes the ion channel expression changes for the most common liver diseases.

\section{Viral hepatitis and ion channels}

It is estimated that 350 million people are chronic hepatitis B virus (HBV) carriers in the world, and that up to $30 \%$ of them develop progressive chronic liver disease appearing as hepatitis, fibrosis, cirrhosis, and $\mathrm{HCC}^{[47]}$. HBV infection produces chronic necro-inflammation with subsequent fibrosis and hepatocyte proliferation. One of the viral factors potentially involved in HBV-related hepatocarcinogenesis is the $\mathrm{HBx}$ protein, which promotes cell cycle progression and inactivates negative growth regulators. This protein also binds to and inhibits the expression of $p 53$, as well as other tumor suppressor genes and senescence-related factors $^{[3,48-50]}$. The HBx protein regulates calcium signaling through the activation of store-operated calcium channels (SOCs), which stimulate HBV replication ${ }^{[1,52]}$. In addition, HBx can activate SOCs by binding C-terminal of Orail protein channels ${ }^{[53]}$. Interestingly, co-immunoprecipitation experiments and pull-down assays demonstrated the interaction between $\mathrm{HBx}$ and the Orai1 protein; the C-terminus of the Orai1 protein was involved in such interaction. The authors concluded that the HBx protein binds to the STIM1Orai1 complexes regulating the activity of $\mathrm{SOCs}^{[53]}$. In this same direction, the HBV PreS2-mutant large surface antigen activates store-operated calcium entry and promotes chromosome instability ${ }^{[54]}$.

On the other hand, miR-125b inhibits HBV expression in vitro by targeting the sodium channel SCNN1A gene $^{[55]}$. It has also been observed that $\mathrm{P} 2 \mathrm{X} 7$ function is necessary for the infection of human hepatocytes by $\mathrm{HBV}$. Because $\mathrm{P} 2 \mathrm{X} 7$ activation is a major component of inflammatory responses, HBV may contribute to liver inflammation ${ }^{[56]}$.

In the case of hepatitis $\mathrm{C}$ virus (HCV) infections, it is estimated that 130 million people have chronic HCV infection and most of them develop chronic liver disease ${ }^{[47]}$. Continuous inflammation and hepatocyte regeneration in the setting of chronic hepatitis and subsequent progression to cirrhosis are thought to lead to chromosomal damage, and possibly to initiate hepatic carcinogenesis. HCV also induces steatosis; oxidative stress causes steatohepatitis and these pathways lead to liver injury or HCC in chronic HCV infection ${ }^{[3,57,58]}$. Interestingly, the HCV p7 protein forms a cation channel in vitro ${ }^{[59-61]}$, and p7 deletions and point mutations markedly reduce the production of infectious virions in cell culture ${ }^{[61-63]} \cdot \mathrm{p} 7$ is a proton channel required for the production of infectious virions ${ }^{[6]]}$. There are some small molecules that block the p7 channel function and virion production in culture, rendering it an attractive antiviral target ${ }^{[5,65-71]}$.

$\mathrm{P} 2 \mathrm{X} 4$ receptors expression form part of the purinergic signaling complex in HCV-induced liver pathogenesis ${ }^{[72,73]}$. Additionally, the modulation of the gamma-aminobutyric acid type A (GABA-A) receptor activity was observed in several chronic hepatitis failures, including hepatitis $C$. Increased expression of GABA-A $\alpha 1$ receptor subunit, and decreased expression of GABA-A $\beta 3$ subunit have been found in chronic hepatitis $\mathrm{C}$ patients. Thus, the expression of GABA-A receptor subunits may be associated with either current or previous HCV infection ${ }^{[74]}$. 
Table 1. Ion channel expression in major liver diseases

\begin{tabular}{|c|c|c|c|c|c|c|c|}
\hline $\begin{array}{l}\text { Liver } \\
\text { disease }\end{array}$ & $\begin{array}{l}\text { Channel/ } \\
\text { Transporter }\end{array}$ & $\begin{array}{l}\text { Gene } \\
\text { symbol }\end{array}$ & Developed name & $\begin{array}{l}\text { Trans- } \\
\text { ported } \\
\text { ion(s) }\end{array}$ & $\begin{array}{c}\text { Genomic } \\
\text { mapping } \\
\text { (chromosome in } \\
\text { homo sapiens) }\end{array}$ & $\begin{array}{c}\text { Expression } \\
\text { change } \\
\text { (compared to } \\
\text { normal tissue) }\end{array}$ & Ref. \\
\hline \multirow{6}{*}{$\begin{array}{l}\text { Viral } \\
\text { hepatitis }\end{array}$} & p7 & -- & Hepatitis C virus p7 protein & $\mathrm{Ca}^{2+}$ & -- & Overexpression & {$[59-61]$} \\
\hline & SCNN1A & SCNN1A & $\begin{array}{l}\text { Sodium channel non-voltage- } \\
\text { gated } 1 \text { alpha }\end{array}$ & $\mathrm{Na}^{+}$ & 12 & Overexpression & {$[55]$} \\
\hline & $\mathrm{P} 2 \times 7$ & $P 2 R X 7$ & $\begin{array}{l}\text { Purinergic receptor } \mathrm{P} 2 \mathrm{X} \text {, ligand- } \\
\text { gated ion channel } 7\end{array}$ & $\mathrm{Na}^{+}, \mathrm{Ca}^{2+}$ & 12 & Overexpression & {$[56]$} \\
\hline & $\mathrm{P} 2 \times 4$ & $P 2 R \times 4$ & $\begin{array}{l}\text { Purinergic receptor } \mathrm{P} 2 \mathrm{X} \text {, ligand- } \\
\text { gated ion channel } 4\end{array}$ & $\mathrm{Na}^{+}, \mathrm{Ca}^{2+}$ & 12 & Overexpression & {$[72,73]$} \\
\hline & SOCs & ORA/1 & $\begin{array}{l}\text { Calcium release- activated } \\
\text { calcium modulator }\end{array}$ & $\mathrm{Ca}^{2+}$ & 12 & Overexpression & {$[51-54]$} \\
\hline & GABA A $\alpha 1$ & GABRA1 & $\begin{array}{l}\text { Gamma-aminobutyric acid type } \\
\text { A receptor alpha } 1 \text { subunit }\end{array}$ & $\mathrm{Cl}^{-}$ & 5 & Overexpression & {$[74]$} \\
\hline \multirow[t]{5}{*}{ NAFLD } & $\mathrm{K}_{\text {Са3.1 }}$ & KCNN4 & $\begin{array}{l}\text { Calcium-activated potassium } \\
\text { channel subfamily } \mathrm{N} \text { member } 4\end{array}$ & $\mathrm{~K}^{+}$ & 19 & Overexpression & {$[79,80]$} \\
\hline & $P 2 \times 7$ & $P 2 R X 7$ & $\begin{array}{l}\text { Purinergic receptor } \mathrm{P} 2 \mathrm{X} \text {, ligand- } \\
\text { gated ion channel } 7\end{array}$ & $\mathrm{Na}^{+}, \mathrm{Ca}^{2+}$ & 12 & Overexpression & {$[81-83]$} \\
\hline & SOCs & -- & Store-operated calcium channels & $\mathrm{Ca}^{2+}$ & NS & Overexpression & {$[8,84]$} \\
\hline & $\mathrm{TPC} 2$ & TPCN2 & Two-pore segment channel 2 & $\mathrm{Ca}^{2+}$ & 11 & Overexpression & {$[21,85]$} \\
\hline & TRPV1 & TRPV1 & $\begin{array}{l}\text { Transient receptor potential } \\
\text { cation channel subfamily } \vee \\
\text { member } 1\end{array}$ & $\begin{array}{l}\text { Non } \\
\text { selective } \\
\text { cation }\end{array}$ & 17 & Overexpression & {$[86,87]$} \\
\hline \multirow[t]{4}{*}{ Fibrosis } & TRPV4 & TRPV4 & $\begin{array}{l}\text { Transient receptor potential } \\
\text { cation channel subfamily } \vee \\
\text { member } 4\end{array}$ & $\begin{array}{l}\text { Non- } \\
\text { selective } \\
\text { cation }\end{array}$ & 12 & Overexpression & {$[88]$} \\
\hline & TRPC6 & TRPC6 & $\begin{array}{l}\text { Transient receptor potential } \\
\text { cation channel subfamily } C \\
\text { member } 6\end{array}$ & $\mathrm{Ca}^{2+}$ & 11 & Overexpression & {$[89]$} \\
\hline & TRPM7 & TRPMT & $\begin{array}{l}\text { Transient receptor potential } \\
\text { cation channel subfamily M } \\
\text { member } 7\end{array}$ & $\mathrm{Ca}^{2+}, \mathrm{Mg}^{2+}$ & 15 & Overexpression & [90] \\
\hline & ASIC1a & $A S / C 1$ & $\begin{array}{l}\text { Acid sensing ion channel subunit } \\
1\end{array}$ & $\mathrm{Na}^{+}$ & 12 & Overexpression & {$[91]$} \\
\hline \multirow[t]{9}{*}{ Cirrhosis } & TRPV2 & TRPV2 & $\begin{array}{l}\text { Transient receptor potential } \\
\text { cation channel subfamily } \vee \\
\text { member } 2\end{array}$ & $\begin{array}{l}\text { Non- } \\
\text { selective } \\
\text { cation }\end{array}$ & 17 & Overexpression & [95] \\
\hline & TRPC6 & TRPC6 & $\begin{array}{l}\text { Transient receptor potential } \\
\text { cation channel subfamily } C \\
\text { member } 6\end{array}$ & $\mathrm{Ca}^{2+}$ & 11 & Overexpression & {$[96]$} \\
\hline & $\mathrm{Nav}_{1.2}$ & $S C N 2 A$ & $\begin{array}{l}\text { Voltage-gated sodium channel } \\
\text { alpha subunit } 2\end{array}$ & $\mathrm{Na}^{+}$ & 2 & Overexpression & {$[96]$} \\
\hline & $\mathrm{K}_{\mathrm{Ca} .1}$ & KCNN4 & $\begin{array}{l}\text { Calcium-activated potassium } \\
\text { channel subfamily } \mathrm{N} \text { member } 4\end{array}$ & $\mathrm{~K}^{+}$ & 19 & Overexpression & [96] \\
\hline & $\mathrm{ABCC} 3$ & $A B C C 3$ & $\begin{array}{l}\text { ATP binding cassette subfamily C } \\
\text { member } 3\end{array}$ & -- & 17 & Overexpression & [96] \\
\hline & ITPRs & ITPR & $\begin{array}{l}\text { Inositol 1,4,5-trisphosphate } \\
\text { receptor }\end{array}$ & $\mathrm{Ca}^{2+}$ & NS & Overexpression & [97] \\
\hline & AQP1 & $A Q P 1$ & Aquaporin 1 & $\begin{array}{l}\text { water } \\
\text { channel }\end{array}$ & 7 & Overexpression & [98-100] \\
\hline & $\mathrm{K}_{\mathrm{Ca} 1.1}(\mathrm{BK})$ & KCNMA1 & $\begin{array}{l}\text { Calcium-activated potassium } \\
\text { channel subfamily } \mathrm{M} \text { alpha } 1\end{array}$ & $\mathrm{~K}^{+}$ & 10 & Overexpression & {$[21,101]$} \\
\hline & NCC & $S L C 12 A 3$ & Solute carrier family 12 member 3 & $\mathrm{Na}^{+}, \mathrm{Cl}^{-}$ & 16 & Overexpression & {$[102]$} \\
\hline \multirow[t]{5}{*}{$\mathrm{HCC}$} & $\mathrm{K}_{\mathrm{Ca} 3.1}$ & KCNN4 & $\begin{array}{l}\text { Calcium-activated potassium } \\
\text { channel subfamily } \mathrm{N} \text { member } 4\end{array}$ & $\mathrm{~K}^{+}$ & 19 & Overexpression & {$[103,104]$} \\
\hline & KCNQ1 & KCNQ1 & $\begin{array}{l}\text { Voltage-gated potassium channel } \\
\text { subfamily Q member } 1\end{array}$ & $\mathrm{~K}^{+}$ & 11 & Downregulation & {$[105]$} \\
\hline & KCNJ11 & KCNJ11 & $\begin{array}{l}\text { Inwardly rectifying potassium } \\
\text { channel subfamily J member } 1\end{array}$ & $\mathrm{~K}^{+}$ & 11 & Overexpression & {$[106]$} \\
\hline & $\mathrm{K}_{\text {ATP }}$ channels & -- & $\begin{array}{l}\text { ATP-sensitive potassium } \\
\text { channels }\end{array}$ & $\mathrm{K}^{+}$ & NS & Overexpression & [37] \\
\hline & Eag1 & KCNHI & $\begin{array}{l}\text { Voltage-gated potassium channel } \\
\text { subfamily } \mathrm{H} \text { member } 1\end{array}$ & $\mathrm{~K}^{+}$ & 1 & Overexpression & {$[115]$} \\
\hline
\end{tabular}




\begin{tabular}{|c|c|c|c|c|c|c|}
\hline $\begin{array}{l}\text { T-type } \mathrm{Ca}^{2+} \\
\text { channels }\end{array}$ & $\begin{array}{l}\text { CACNA1G } \\
\text { CACNA1H } \\
\text { CACNA11 }\end{array}$ & Voltage-gated calcium channels & $\mathrm{Ca}^{2+}$ & $\begin{array}{l}17 \\
16 \\
22\end{array}$ & Overexpression & [117] \\
\hline $\mathrm{P} 2 \mathrm{X} 3$ & $P 2 R \times 3$ & $\begin{array}{l}\text { Purinergic receptor P2X, ligand } \\
\text { gated ion channel } 3\end{array}$ & $\mathrm{Na}^{+}, \mathrm{Ca}^{2+}$ & 11 & Overexpression & [119] \\
\hline SOCs & ORA/1 & Store-operated calcium channels & $\mathrm{Ca}^{2+}$ & 12 & Overexpression & {$[120,121]$} \\
\hline $\mathrm{ClC}-3$ & CLCN3 & Voltage-gated chloride channel 3 & $\mathrm{Cl}^{-}$ & 4 & Overexpression & {$[122]$} \\
\hline CLIC1 & $C L / C 1$ & Chloride intracellular channel 1 & $\mathrm{Cl}^{-}$ & 6 & Overexpression & {$[123]$} \\
\hline VGSC $\beta 1$ & $S C N 1 B$ & $\begin{array}{l}\text { Voltage-gated sodium channel } \\
\text { beta subunit } 1\end{array}$ & $\mathrm{Na}^{+}$ & 19 & Downregulation & [124] \\
\hline $\mathrm{Nav}_{1.2}$ & $S C N 2 A$ & $\begin{array}{l}\text { Voltage-gated sodium channel } \\
\text { alpha subunit } 2\end{array}$ & $\mathrm{Na}^{+}$ & 2 & Overexpression & [96] \\
\hline AQP5 & AQP5 & Aquaporin 5 & $\begin{array}{l}\text { water } \\
\text { channel }\end{array}$ & 12 & Overexpression & {$[125,126]$} \\
\hline AQP9 & $A Q P Q$ & Aquaporin 9 & $\begin{array}{l}\text { water } \\
\text { channel }\end{array}$ & 15 & Downregulation & {$[127,128]$} \\
\hline TRPC6 & TRPC6 & $\begin{array}{l}\text { Transient receptor potential } \\
\text { cation channel subfamily C } \\
\text { member } 6\end{array}$ & $\mathrm{Ca}^{2+}$ & 11 & Overexpression & [129-131] \\
\hline TRPC1 & TRPC1 & $\begin{array}{l}\text { Transient receptor potential } \\
\text { cation channel subfamily C } \\
\text { member } 1\end{array}$ & $\begin{array}{l}\text { Non- } \\
\text { selective } \\
\text { cation }\end{array}$ & 3 & Overexpression & {$[132,133]$} \\
\hline TRPV1 & TRPV1 & $\begin{array}{l}\text { Transient receptor potential } \\
\text { cation channel subfamily } \vee \\
\text { member } 1\end{array}$ & $\begin{array}{l}\text { Non- } \\
\text { selective } \\
\text { cation }\end{array}$ & 17 & Downregulation & {$[134,135]$} \\
\hline TRPV2 & TRPV2 & $\begin{array}{l}\text { Transient receptor potential } \\
\text { cation channel subfamily } \vee \\
\text { member } 2\end{array}$ & $\begin{array}{l}\text { Non- } \\
\text { selective } \\
\text { cation }\end{array}$ & 17 & Overexpression & [136] \\
\hline TRPV4 & TRPVA & $\begin{array}{l}\text { Transient receptor potential } \\
\text { cation channel subfamily } \vee \\
\text { member } 4\end{array}$ & $\begin{array}{l}\text { Non- } \\
\text { selective } \\
\text { cation }\end{array}$ & 12 & Overexpression & [137] \\
\hline TRPM7 & TRPMT & $\begin{array}{l}\text { Transient receptor potential } \\
\text { cation channel subfamily M } \\
\text { member } 7\end{array}$ & $\mathrm{Ca}^{2+}, \mathrm{Mg}^{2+}$ & 15 & Overexpression & [138] \\
\hline ASICla & $A S / C 1$ & $\begin{array}{l}\text { Acid sensing ion channel subunit } \\
1\end{array}$ & $\mathrm{Na}^{+}$ & 12 & Overexpression & [139] \\
\hline ITPR3 & ITPR3 & $\begin{array}{l}\text { Inositol 1,4,5-trisphosphate } \\
\text { receptor type } 3\end{array}$ & $\mathrm{Ca}^{2+}$ & 6 & Overexpression & [141] \\
\hline
\end{tabular}

NS: no specific channel indicated in the original source; HCC: hepatocellular carcinoma; NAFLD: nonalcoholic fatty liver disease; NCC: $\mathrm{NaCl}$ cotransporter

\section{Ion channels in nonalcoholic fatty liver disease and liver fibrosis}

Nonalcoholic fatty liver disease (NAFLD) defines liver abnormalities ranging from simple steatosis (abnormal hepatic fat accumulation) or nonalcoholic fatty liver to nonalcoholic steatohepatitis (NASH) that have been identified as a cause of fibrosis, cirrhosis, and HCC. It is closely related to obesity and metabolic syndrome. The precise mechanism of HCC development from NAFLD has not yet been fully elucidated ${ }^{[3,75-77]}$.

$\mathrm{K}_{\text {Саз.1 }}$ potassium channels are expressed in non-excitable tissues such as epithelia affecting proliferation, migration, and vascular resistance, and play an important role in the modulation of $\mathrm{Ca}^{2+}$ signaling ${ }^{[78]}$. In liver disease, the $\mathrm{K}_{\text {Саз.1 }}$ channel inhibitor TRAM-34 downregulates fibrosis-associated gene expression and reduces portal perfusion pressure ${ }^{[79]}$. It has also been found that the $\mathrm{K}_{\mathrm{Ca3.1}}$ channel inhibitor senicapoc mitigates both steatosis and fibrosis in non-alcoholic liver disease models ${ }^{[80]}$. P2X7 deficiency ${ }^{[81]}$ or blockage attenuates nonalcoholic steatohepatitis ${ }^{[82]}$ and liver fibrosis ${ }^{[83]}$.

Intracellular $\mathrm{Ca}^{2+}$ homeostasis is altered in steatotic hepatocytes. Decreased $\mathrm{Ca}^{2+}$ concentration in the endoplasmic reticulum may lead to endoplasmic reticulum stress, which has been identified as an important mediator of the progression from liver steatosis to nonalcoholic steatohepatitis, type 2 diabetes, and HCC. SOCs are responsible for proper $\mathrm{Ca}^{2+}$ maintenance in the hepatocyte endoplasmic reticulum 
lumen. Accordingly, SOCE is substantially inhibited in steatotic hepatocytes. This inhibition enhances lipid accumulation by positive feedback and may contribute to the development of NASH and insulin resistance $^{[8,84]}$. The antidiabetic drug exendin-4 reverses the lipid-induced inhibition of SOCE and decreases liver lipid with rapid onset ${ }^{[8]}$.

Two-pore channels (TPCs) are cation-selective intracellular ion channels, and their activation mediates calcium release from lysosomal stores. TPC2-deficient mice show hepatic cholesterol accumulation, hyperlipoproteinanemia, and finally $\mathrm{NASH}^{[21,85]}$. Interestingly, the activation of transient receptor potential type vanilloid 1 (TRPV1) by capsaicin prevents nonalcoholic fatty liver disease ${ }^{[86,87]}$. Additionally, the TRPV4, TRPC6, TRPM7, and acid-sensing ion channels (ASIC1a) have been suggested as liver fibrosis mediators. The blockage of these channels inhibits hepatic fibrosis, positioning them as promising therapeutic targets ${ }^{[88-91]}$.

\section{Liver cirrhosis and ion channels}

Liver cirrhosis from any cause is the most important clinical risk factor for HCC with an annual incidence between $2 \%$ and $4 \%$. The transition from chronic liver disease to cirrhosis involves inflammation and activation of hepatic stellate cells with ensuing fibrogenesis and angiogenesis. Liver cirrhosis is characterized by diffuse regenerative nodule of hepatocytes surrounded by dense fibrotic septa with subsequent parenchymal extinction and liver structure collapse. Over time, compensated cirrhosis may progress to decompensated cirrhosis that results in liver failure and death ${ }^{[3,92-94]}$.

As stated above, TRPV4, TRPC6, TRPM7, and ASIC1a channels could act as liver fibrosis mediators. Fibrosis is the prelude to cirrhosis, thus these channels might somehow also modulate cirrhosis. Other studies have also observed over-expression of TRPV2 ${ }^{[95]}$, TRPC6, Nav1.2, and $\mathrm{K}_{\mathrm{Ca3.1}}$ channels as well as the Abcc3 transporter ${ }^{[96]}$ in liver cirrhosis, suggesting them as potential markers of the disease. $\mathrm{Ca}^{2+}$ signals mediate the hepatic effects of numerous hormones and growth factors. Liver $\mathrm{Ca}^{2+}$ signals are elicited by the intracellular $\mathrm{Ca}^{2+}$ channel inositol trisphosphate receptor (ITPRs). Three isoforms of this receptor have been identified, and cirrhosis affects the isoform expression ${ }^{[97]}$.

Some reports have shown an overexpression of AQP1 in liver cirrhosis ${ }^{[98]}$; this protein contributes to microvascular resistance in cirrhosis ${ }^{[99]}$. It has been also proposed that AQP1 polymorphism may be involved in the genetic susceptibility to develop water retention in patients with liver cirrhosis ${ }^{[100]}$. The large conductance $\mathrm{K}_{\mathrm{Ca} 1.1} \mathrm{~K}^{+}$channels $(\mathrm{BK})$ are activated by membrane depolarization and/or elevations in intracellular $\mathrm{Ca}^{2+}$ concentration. Cirrhotic livers display increased activity of BK channels; accordingly, blockage of these channels increased the baseline portal perfusion pressure in cirrhotic livers ${ }^{[21,101]}$. Liver cirrhosis is associated with enhanced renal tubular sodium retention, but the mechanism involved is unknown. Interestingly, liver cirrhosis is associated with increased renal abundance of the $\mathrm{NaCl}$ cotransporter $^{[102]}$. Then, diverse ion channels may serve as potential markers and drug targets for several liver diseases leading to HCC; if so, these proteins could be used as targets for HCC prevention.

\section{Ion channels in hepatocellular carcinoma}

Because the above-mentioned liver diseases may lead to HCC, and because cancer is a multi-factorial disease, a significant amount of ion channels have been studied as potential markers and therapeutic targets of this very poor prognosis malignancy.

Potassium channels play an important role in a variety of carcinoma cells. $\mathrm{K}_{\mathrm{Ca3.1}}$ channels are over-expressed in HCC and the channel blockade with TRAM-34 inhibits HCC cell proliferation in a time- and dosedependent manner ${ }^{[103,104]}$. A recent work showed that KCNQ1 was frequently downregulated in HCC cell lines and HCC tissues, and that HCC patients with low KCNQ1 expression had poor prognosis. Gain-of- 
function studies showed that KCNQ1 exhibited remarkable inhibitory roles on tumor metastasis in vitro and in vivo; thus, this channel could represent a prognostic marker, as well as a promising therapeutic target for $\mathrm{HCC}^{[105]}$. Another study found that the KCNJ11 channel was differentially expressed in HCC, and it predicted the poor prognosis in HCC patients. KCNJ11 promotes tumor progression through interaction with lactate dehydrogenase A (LDHA). Pharmacological inhibition of LDHA or knockdown of KCNJ11 expression inhibited cell proliferation, promoted apoptosis, and reduced cell invasive capacity ${ }^{[106]}$. $\mathrm{K}_{\text {ATP }}$ channels regulate mitogen-induced proliferation in the human liver cell lines HepG2, which could have implications for liver growth control and serve as a potential therapeutic target ${ }^{[37]}$. The voltage-gated potassium channel ether à-go-go-1 (Eag1) has gained enormous interest in cancer research because of its oncogenic properties ${ }^{[107-109]}$. Eag1 channels have also been proposed as early tumor biomarkers and therapeutic targets for different types of cancers ${ }^{[110,111]}$. Moreover, the inhibition of Eag1 reduces tumor cell proliferation in vitro and in vivo ${ }^{[112-114]}$. We reported that HepG2 and HuH-7 HCC cells displayed Eag1 channel expression, and that the anti-histamine astemizole (a non-specific Eag1 inhibitor) decreased cell proliferation and induced apoptosis in both cell lines. In addition, an increase in Eag1 expression was found during HCC development in rats. Astemizole treatment prevented HCC development and seems to induce tumor regression in rats with $\mathrm{HCC}^{[115]}$.

T-type calcium channels play an important role in cell cycle progression in different types of cancer ${ }^{[116]}$. The expression of the three T-type calcium channel subunits was observed in HCC cell lines and T-type channel blockage with mibefradil decreased cell proliferation in the SNU449 cell line ${ }^{[117]}$. P2 purinergic receptors are overexpressed in certain cancer tissues; the levels of $\mathrm{P} 2 \mathrm{Y} 2$ receptor are enhanced in HCC compared with human normal hepatocytes. These receptors are involved in ATP-induced $\left(\mathrm{Ca}^{2+}\right)_{\mathrm{i}}$ increase. Silencing P2Y2R expression inhibited ATP-induced human HCC cell proliferation and migration, and $\mathrm{P} 2 \mathrm{Y} 2 \mathrm{R}$ blockage inhibited cell growth in mice ${ }^{[21,118]}$. In addition, high $\mathrm{P} 2 \mathrm{X} 3$ receptor expression is associated with poor recurrence-free survival in HCC, while high $\mathrm{P} 2 \mathrm{Y} 13$ expression is associated with improved recurrence-free survival. Moreover, extracellular nucleotide treatment induce cell cycle progression and extracellular ATP-mediated activation of $\mathrm{P} 2 \mathrm{X} 3$ receptors promotes proliferation of HCC cells ${ }^{[119]}$. SOCE is a major $\mathrm{Ca}^{2+}$ influx pathway controlling the intracellular $\mathrm{Ca}^{2+}$ concentration in normal hepatocytes and HCC cells, and $\mathrm{Ca}^{2+}$ influx has been demonstrated to be involved in liver oncogenesis. Accordingly, the blockade of SOCE inhibits hepatocarcinoma cell migration and invasion, by regulating focal adhesion turnover $^{[120]}$. The activation of SOCE channels is implicated in cancer cell chemoresistance, although the underlying molecular mechanisms are not well understood. However, inhibition of Orai1-mediated $\mathrm{Ca}^{2+}$ entry enhances chemosensitivity to 5 -fluorouracil of HepG2 hepatocarcinoma cells ${ }^{[121]}$. The specific roles and molecular mechanisms of calcium entry in drug response deserve further investigation.

CIC-3 chloride channels have multiple functions in tumorigenesis and tumor growth in HCC; the CIC-3 channel blocker DIDS (4,4'-diisothiocyanostilbene-2,2'-disulfonic acid) arrests the cell at the G1 phase, inhibiting the proliferation of Hep3B HCC cells ${ }^{[122]}$. Proteomic approaches found that the chloride intracellular channel 1 (CLIC1) is upregulated in HCC tissues, and that it participates in HCC migration and invasion by targeting maspin ${ }^{[123]}$.

The voltage-gated sodium channel $\beta 1$ subunit was proposed as a cell adhesion molecule in some HCC cell lines. The analgesic-antitumor peptide (a scorpion toxin polypeptide with antitumor activity) inhibits the migration and invasion of HepG2 cells by an upregulated VGSC $\beta 1$ subunit ${ }^{[124]}$. Additionally the overexpression of $\mathrm{Nav}_{1.2}$ channels has been observed in an HCC in vivo model ${ }^{[96]}$.

AQP5 is highly expressed in HCC cell lines and its downregulation inhibits HCC cell invasion and tumor metastasis. Downregulation of AQP5 suppressed the epithelial-to-mesenchymal transition process in HCC cells $^{[125]}$. Another report found that microRNA-325-3p inhibits cell proliferation and induces apoptosis 
in $\mathrm{HBV}$-related hepatocellular carcinoma by downregulation of $\mathrm{AQP} 5^{[126]}$. These findings suggest that AQP5 may be a potential therapeutic target for HCC. AQP9 is the main aquaglyceroporin in the liver and its mRNA and protein levels are downregulated in HCC tissues compared to normal hepatocytes. Moreover, AQP9 over-expression inhibits hepatocellular carcinoma by upregulating FOXO1 expression, and suppresses invasion by inhibiting epithelial-to-mesenchymal transition. These findings suggest that the restoration of AQP9 expression can inhibit development of liver cancer ${ }^{[127,128]}$.

The TRP channel family has gained great relevance due to its role in several diseases. A recent study investigated the roles of the $\mathrm{Na}^{+} / \mathrm{Ca}^{2+}$ exchanger $1(\mathrm{NCX} 1)$ and the canonical transient receptor potential channel 6 (TRPC6) in regulating TGF $\beta$ in human HCC. They found that TGF $\beta$ induces the formation and activation of a TRPC6/NCX1 molecular complex, which mediates the effects of TGF $\beta$ on the migration, invasion, and intrahepatic metastasis of HCC. These findings suggest TRPC6 and NCX1 as potential targets for HCC therapy ${ }^{[129,130]}$. HCC develops multi-drug resistance in most cases; interestingly, multidrug resistance regulation by TRPC 6 and calcium-dependence has been shown in HCC cells ${ }^{[131]}$. Silencing of TRPC1 channels suppressed cell proliferation while store-operated $\mathrm{Ca}^{2+}$ entry was significantly increased ${ }^{[132,133]}$. On the other hand, it has been found that high expression of the vanilloid receptor-1 (TRPV1) is associated with better prognosis of HCC patients ${ }^{[134]}$.

The combined effect of static magnetic field and anti-cancer drugs has gained great interest in cancer. Static magnetic field enhances the anti-cancer effect of capsaicin on HepG2 cells through the mitochondriadependent apoptosis pathway. This synergy may be explained if static magnetic field increased the binding efficiency of capsaicin to TRPV1 channels ${ }^{[135]}$. TRPV2 contributes to the stemness of liver cancer and is a potential target in the treatment of human liver cancer patients ${ }^{[136]}$. TRPV4 is over-expressed in HCC tissues when compared with non-tumoral liver. Furthermore, pharmacological inhibition of TRPV4 suppressed cell proliferation, induced apoptosis, and decreased the cell migration capability by attenuating the epithelial-to-mesenchymal transition process in HCC via modulation of the ERK signaling pathway ${ }^{[137]}$. TRPM7 channels play a role in the migration and invasion of different types of cancer; actually, bradykinin promotes cell migration and invasion of HCC cells via TRPM7 channels ${ }^{[138]}$.

ASICs are $\mathrm{H}^{+}-\mathrm{Ca}^{2+}$-, and $\mathrm{Na}^{+}$-gated cation channels activated by changes in the extracellular $\mathrm{pH}$, and ASIC1 $\alpha$ (ASIC1a) has been associated with tumor proliferation and migration. ASIC1 $\alpha$ is overexpressed in HCC tissues and associated with advanced clinical stage. Silencing of ASIC1 $\alpha$ expression inhibited the migration and invasion of HCC cells, suggesting a novel approach for HCC therapy ${ }^{[139]}$.

The R-Tf-D-LP4 cell-penetrating peptide derived from the mitochondrial multifunctional protein VDAC1 (voltage-dependent anion channel) induced apoptosis in liver cancer cell lines and inhibited liver tumor growth in vivo, representing a promising therapeutic approach for $\mathrm{HCC}^{[140]}$. Inositol 1,4,5-trisphosphate receptors (ITPRs) are intracellular $\mathrm{Ca}^{2+}$ channels. ITPR3 is either absent or expressed at low levels in normal hepatocytes, but it is over-expressed in HCC patients; its increased expression level was associated with poor survival. Besides, cell proliferation and liver regeneration were enhanced in vivo, and ITPR3 deletion in human HCC cells increased apoptosis ${ }^{[141]}$.

\section{Discussion: ion channels as potential tools for chronic liver diseases and HCC prevention, diagnosis, and therapy}

HCC is a leading cause of cancer-death worldwide and is one of the most chemo-resistant tumors ${ }^{[3,142]}$. The combination of new therapeutic targets with existing therapies may be very helpful. Several ion channels play very important roles in cancer-associated processes including inflammation, oxidative stress, cell proliferation, apoptosis, migration, invasion, angiogenesis, metastases, and drug response. These proteins are differentially expressed in HCC and liver diseases compared to their expression in the healthy 
Table 2. Ion channel inhibitors as potential therapeutic agents studied in HCC

\begin{tabular}{|c|c|c|c|}
\hline Inhibitor & Targeted ion channel & Ion channel gene symbol ${ }^{*}$ & Ref. \\
\hline TRAM-34 & $\mathrm{K}_{\text {саз.1 }}$ & KCNN4 & {$[103,104]$} \\
\hline ASTEMIZOLE & Eag1, Herg & KCNH1, KCNH2 & [115] \\
\hline MIBEFRADIL & T-type $\mathrm{Ca}^{2+}$ channels & -- & [117] \\
\hline 2-APB, SKF96365 & SOCs & -- & {$[21,118,121]$} \\
\hline DIDS & $\mathrm{CIC}-3$ & CLCN3 & [122] \\
\hline MicroRNA-325-3P & AQP5 & AQP5 & [126] \\
\hline CAPSAICIN & TRPV1 & TRPV1 & [135] \\
\hline HC-067047 & TRPV4 & TRPV4 & [137] \\
\hline
\end{tabular}

*When the specific ion channel has been reported to be targeted. HCC: hepatocellular carcinoma

Table 3. Ion channels suggested as HCC prognostic markers

\begin{tabular}{lcll}
\hline Channel & Gene symbol & Expression in HCC & Association to prognosis \\
\hline KCNQ1 & $K C N Q 1$ & Downregulated & Poor prognosis \\
KCNJ11 & $K C N J 11$ & Differentially expressed & Poor prognosis \\
P2X3 & $P 2 R X 3$ & Overexpression & Poor recurrence-free survival \\
TRPV1 & TRPV1 & Overexpression & Better prognosis \\
ASIC1a & AS/C1 & Overexpression & Advanced clinical stage \\
ITPR3 & ITPR3 & Overexpression & Poor survival \\
\hline
\end{tabular}

HCC: hepatocellular carcinoma

liver. Thus, patients at risk of developing some liver diseases, e.g., people infected with hepatitis viruses, patients with liver cirrhosis, or those suffering from alcoholism, might be candidates in whom ion channel expression can be studied. Nevertheless, an important issue to solve is how to detect ion channel expression in not easily accessible tissues such as the liver. An option may be ion channel detection by imaging studies. For instance, Eag1 channel expression has been detected in vivo with labeled antibodies and near-infrared imaging techniques, even in non-palpable tumors, in mice ${ }^{[143]}$. Another option may be the detection of ion channels in extracellular vesicles released to the bloodstream by the liver. The investigation of ion channel expression in extracellular vesicles released by the liver in different pathological conditions is needed. These approaches should benefit patients by being diagnosed at earlier stages of the disease.

The precise molecular mechanisms involved in the association of ion channel function with cancer remain elusive. The antiproliferative effect of channel blockage on cell proliferation indicates that ion flux may play an important role. However, non-canonical functions of ion channel may also play a role, as occurs in other tissues and diseases ${ }^{[144]}$. For instance, mutant non-conducting Kv10.1 potassium channels partially preserve their oncogenic potential ${ }^{[145]}$. On the other hand, cleavage and translocation to the nucleus of a fragment of the carboxy-terminus of some calcium channels induce the transcription of genes associated with proliferation ${ }^{[146]}$. Thus, the potential role of non-canonical functions of ion channels in liver diseases warrants investigation.

In accordance with the potential role of ion channels in liver diseases, blockage of over-expressed ion channels or activation of downregulated channels results in the inhibition of hepatitis virus replication, development of NAFLD, NASH, liver cirrhosis, and/or HCC [Table 2].

However, because of the relevance of ion channels in normal physiology, targeting these proteins may have non-desirable side-effects. In this direction, drug repurposing is a very good alternative to reduce costs and time for approval, as well as unknown side effects. Actually, several drugs have been suggested for repurposing in cancer, including anti-histamines such as astemizole (which also blocks potassium channels) and loratadine, as well as calcium and potassium channel blockers such as mibefradil and glibenclamide, respectively ${ }^{[147,148]}$. 


\section{Changes in ion channel expression}

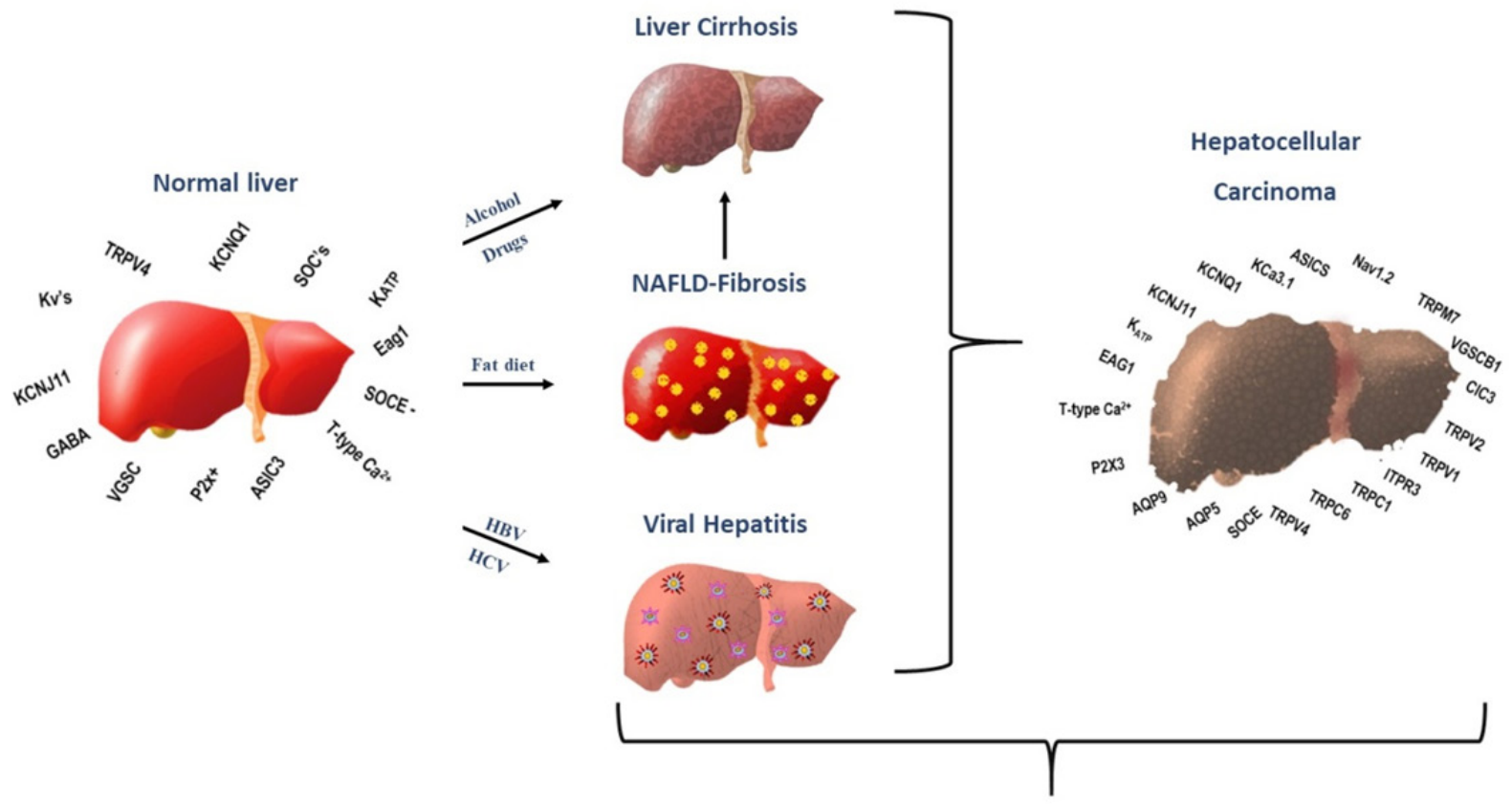

Specific channel block or activation

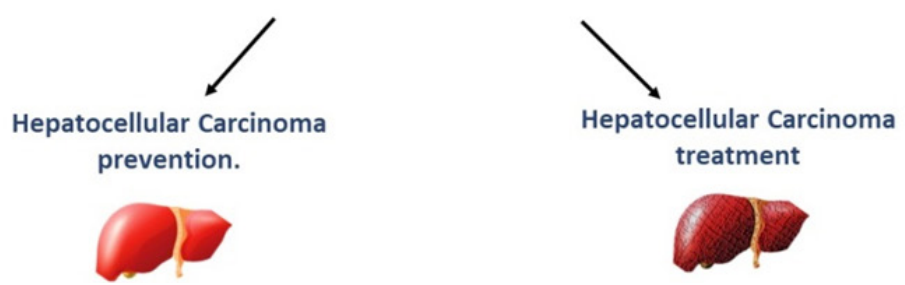

Figure 1. Ion channel-based therapy for HCC prevention and treatment. The expression of several ion channels is altered in liver disorders leading to HCC, as well as in HCC. Because of the very relevant participation of ion channels in cellular processes leading to HCC, targeting either the expression or activity of these proteins may lead to the prevention and treatment of liver diseases including HCC. HCC: hepatocellular carcinoma; HCV: hepatitis C virus; HBV: hepatitis B virus; NAFLD: nonalcoholic fatty liver disease

\section{CONCLUSION}

Ion channels offer a plethora of opportunities for the prevention, diagnosis, and treatment of liver diseases [Figure 1], as well as represent potential tools as HCC prognostic markers [Table 3]. This ion-channelbased approach may help to reduce the mortality of this very poor prognosis disease.

\section{DECLARATION}

\section{Authors' contributions}

Contributed to the conception and design of the review, wrote the paper and revised the final draft: Chávez-López MG, Cruz-Díaz A, Tlapalcoyoa-Apanco KN, Pérez-Carreón JI, Camacho J

\section{Availability of data and materials}

Not applicable.

\section{Financial support and sponsorship}

None. 


\section{Conflicts of interest}

All authors declared that there are not conflicts of interest.

\section{Ethical approval and consent to participate}

Not applicable.

\section{Consent for publication}

Not applicable.

\section{Copyright}

(c) The Author(s) 2020.

\section{REFERENCES}

1. American Cancer Society. Cancer Facts \& Figures, 2019. Available from: https:/www.cancer.org/content/dam/cancer-org/research/ cancer-facts-and-statistics/annual-cancer-facts-and-figures/2019/cancer-facts-and-figures-2019.pdf [Last accessed on 26 Mar 2020]

2. World Health Organization, Cancers, 2010. Available from: https://www.who.int/nmh/publications/fact_sheet_cancers_en.pdf [Last accessed on 26 Mar 2020]

3. Chávez-López MG, Zúñiga-García V, Pérez-Carreón JI, Avalos-Fuentes A, Escobar Y, et al. Eag1 channels as potential early-stage biomarkers of hepatocellular carcinoma. Biologics 2016;10:139-48.

4. Mittal S, El-Serag HB. Epidemiology of hepatocellular carcinoma: consider the population. J Clin Gastroenterol 2013;47:S2-6.

5. Jemal A, Siegel R, Ward E, Hao Y, Xu J, et al. Cancer statistics, 2008. CA Cancer J Clin 2008;58:71-96.

6. Chuang SC, La Vecchia C, Boffetta P. Liver cancer: descriptive epidemiology and risk factors other than HBV and HCV infection. Cancer Lett 2009;286:9-14.

7. Gomes MA, Priolli DG, Tralhão JG, Botelho MF. Hepatocellular carcinoma: epidemiology, biology, diagnosis, and therapies. Rev Assoc Med Bras (1992) 2013;59:514-24.

8. Ali ES, Rychkov GY, Barritt GJ. Metabolic disorders and cancer: hepatocyte store-operated $\mathrm{Ca}^{2+}$ channels in nonalcoholic fatty liver disease. Adv Exp Med Biol 2017;993:595-621.

9. Herbst DA, Reddy KR. Risk factors for hepatocellular carcinoma. Clin Liver Dis (Hoboken) 2012;1:180-2.

10. Sherman M, Llovet JM. Smoking, hepatitis B virus infection, and development of hepatocellular carcinoma. J Natl Cancer Inst 2011;103:1642-3.

11. Bruix J, Llovet JM. Hepatitis B virus and hepatocellular carcinoma. J Hepatol 2003;39:S59-63.

12. Barker BS, Young GT, Soubrance CH, Stephens GJ, Stevens EB, et al. Conn's Translational Neuroscience, Chapter 2- Ion Channels. Academic Press; 2017. pp. 11-43.

13. Martial S. Involvement of ion channels and transporters in carcinoma angiogenesis and metastasis. Am J Physiol Cell Physiol 2016;310:C710-27.

14. Lang F, Stournaras C. Ion channels in cancer: future perspectives and clinical potential. Philos Trans R Soc Lond B Biol Sci 2014;369:20130108

15. Catterall WA. Voltage-gated calcium channels. Cold Spring Harb Perspect Biol 2011;3:a003947.

16. Berridge MJ, Bootman MD, Roderick HL. Calcium signalling: dynamics, homeostasis and remodelling. Nat Rev Mol Cell Biol 2003;4:517-29.

17. Prevarskaya N, Ouadid-Ahidouch H, Skryma R, Shuba Y. Remodelling of $\mathrm{Ca}^{2+}$ transport in cancer: how it contributes to cancer hallmarks? Philos Trans R Soc Lond B Biol Sci 2014;369:20130097.

18. Taylor JT, Zeng XB, Pottle JE, Lee K, Wang AR, et al. Calcium signaling and T-type calcium channels in cancer cell cycling. World J Gastroenterol 2008;14:4984-91

19. Roderick HL, Cook SJ. $\mathrm{Ca}^{2+}$ signalling checkpoints in cancer: remodelling $\mathrm{Ca}^{2+}$ for cancer cell proliferation and survival. Nat Rev Cancer 2008;8:361-75.

20. Kuang Q, Purhonen P, Hebert H. Structure of potassium channels. Cell Mol Life Sci 2015;72:3677-93.

21. Ramirez A, Vazquez-Sanchez AY, Carrion-Robalino N, Camacho J. Ion channels and oxidative stress as a potential link for the diagnosis or treatment of liver diseases. Oxid Med Cell Longev 2016;2016:3928714.

22. Pardo LA, Stuhmer W. The roles of $\mathrm{K}^{+}$channels in cancer. Nat Rev Cancer 2014;14:39-48.

23. Angus M, Ruben P. Voltage gated sodium channels in cancer and their potential mechanisms of action. Channels (Austin) 2019;13:400-9.

24. Djamgoz MBA, Onkal R. Persistent current blockers of voltage-gated sodium channels: a clinical opportunity for controlling metastatic disease. Recent Pat Anticancer Drug Discov 2013;8:66-84

25. Fraser SP, Ozerlat-Gunduz I, Brackenbury WJ, Fitzgerald EM, Campbell TM, et al. Regulation of voltage-gated sodium channel expression in cancer: hormones, growth factors and auto-regulation. Philos Trans R Soc Lond B Biol Sci 2014;369:20130105.

26. Brackenbury WJ. Voltage-gated sodium channels and metastatic disease. Channels (Austin) 2012;6:352-61.

27. Verkman AS, Galietta LJ. Chloride channels as drug targets. Nat Rev Drug Discov 2009;8:153-71. 
28. Turner KL, Sontheimer $\mathrm{H} . \mathrm{Cl}^{-}$and $\mathrm{K}^{+}$channels and their role in primary brain tumour biology. Philos Trans R Soc Lond B Biol Sci 2014;369:20130095.

29. Li RK, Zhang J, Zhang YH, Li ML, Wang M, et al. Chloride intracellular channel 1 is an important factor in the lymphatic metastasis of hepatocarcinoma. Biomed Pharmacother 2012;66:167-72.

30. Saberbaghi T, Wong R, Rutka JT, Wang GL, Feng ZP, et al. Role of Cl- channels in primary brain tumor. Cell Calcium 2019;81:1-11.

31. Zhang S, Wang XM, Yin ZY, Zhao WX, Zhou JY, et al. Chloride intracellular channel 1 is overexpression in hepatic tumor and correlates with a poor prognosis. APMIS 2013;121:1047-53.

32. Jablonski EM, Mattocks MA, Sokolov E, Koniaris LG, Hughes FM Jr, et al. Decreased aquaporin expression leads to increased resistance to apoptosis in hepatocellular carcinoma. Cancer Lett 2007;250:36-46.

33. Pelagalli A, Squillacioti C, Mirabella N, Meli R. Aquaporins in health and disease: an overview focusing on the gut of different species. Int J Mol Sci 2016;17.

34. Gregoire F, Lucidi V, Zerrad-Saadi A, Virreira M, Bolaky N, et al. Analysis of aquaporin expression in liver with a focus on hepatocytes. Histochem Cell Biol 2015;144:347-63.

35. Zhu S, Ran J, Yang B, Mei Z. Aquaporins in digestive system. Adv Exp Med Biol 2017;969:123-30.

36. Aguilar-Bryan L, Nichols CG, Wechsler SW, Clement JP, Boyd AE, et al. Cloning of the beta cell high-affinity sulfonylurea receptor: a regulator of insulin secretion. Science 1995;268:423-6.

37. Malhi H, Irani AN, Rajvanshi P, Suadicani SO, Spray DC, et al. KATP channels regulate mitogenically induced proliferation in primary rat hepatocytes and human liver cell lines. Implications for liver growth control and potential therapeutic targeting. J Biol Chem 2000;275:26050-7.

38. Mohamed YS, Ahmed LA, Salem HA, Agha AM. Role of nitric oxide and KATP channel in the protective effect mediated by nicorandil in bile duct ligation-induced liver fibrosis in rats. Biochem Pharmacol 2018;151:135-42.

39. Nogueira MA, Coelho AM, Sampietre SN, Patzina RA, Pinheiro da Silva F, et al. Beneficial effects of adenosine triphosphate-sensitive $\mathrm{K}^{+}$channel opener on liver ischemia/reperfusion injury. World J Gastroenterol 2014;20:15319-26.

40. Burnstock G, Vaughn B, Robson SC. Purinergic signalling in the liver in health and disease. Purinergic Signal 2014;10:51-70.

41. Burnstock G. Purinergic signalling: therapeutic developments. Front Pharmacol 2017;8:661.

42. Doctor RB, Matzakos T, McWilliams R, Johnson S, Feranchak AP, et al. Purinergic regulation of cholangiocyte secretion: identification of a novel role for P2X receptors. Am J Physiol Gastrointest Liver Physiol 2005;288:G779-86.

43. Emmett DS, Feranchak A, Kilic G, Puljak L, Miller B, et al. Characterization of ionotrophic purinergic receptors in hepatocytes. Hepatology 2008;47:698-705.

44. Zhang Y, Zhang T, Wu C, Xia Q, Xu D. ASICla mediates the drug resistance of human hepatocellular carcinoma via the Ca ${ }^{2+} / \mathrm{PI} 3-\mathrm{kinase}^{-}$ AKT signaling pathway. Lab Invest 2017;97:53-69.

45. Ali ES, Rychkov GY, Barrit GJ. Deranged hepatocyte intracelular $\mathrm{Ca}^{2+}$ homeoatasis and the progression of non-alcoholic fatty liver disease to hepatocellular carcinoma. Cell Calcium 2019;82:102057.

46. Jimenez H, Wang M, Zimmerman JW, Pennison MJ, Sharma S, et al. Tumour-specific amplitude-modulated radiofrequency electromagnetic fields induce differentiation of hepatocellular carcinoma via targeting Cav3.2 T-type voltage-gated calcium channels and $\mathrm{Ca}^{2+}$ influx. EBiomedicine 2019. 44:209-24.

47. Arzumanyan A, Reis HM, Feitelson MA. Pathogenic mechanisms in HBV- and HCV-associated hepatocellular carcinoma. Nat Rev Cancer 2013;13:123-35.

48. Kew MC. Hepatitis B virus x protein in the pathogenesis of hepatitis B virus-induced hepatocellular carcinoma. J Gastroenterol Hepatol 2011;26:144-52.

49. Geng M, Xin X, Bi LQ, Zhou LT, Liu XH. Molecular mechanism of hepatitis B virus X protein function in hepatocarcinogenesis. World J Gastroenterol 2015;21:10732-8.

50. Tarocchi M, Polvani S, Marroncini G, Galli A. Molecular mechanism of hepatitis B virus-induced hepatocarcinogenesis. World J Gastroenterol 2014;20:11630-40.

51. Casciano JC, Bouchard MJ. Hepatitis B virus X protein modulates cytosolic $\mathrm{Ca}^{2+}$ signaling in primary human hepatocytes. Virus Res 2018;246:23-7.

52. Bouchard MJ, Wang LH, Schneider RJ. Calcium signaling by HBx protein in hepatitis B virus DNA replication. Science 2001;294:23768.

53. Yao JH, Liu ZJ, Yi JH, Wang J, Liu YN. Hepatitis B Virus X protein upregulates intracellular calcium signaling by binding C-terminal of orail protein. Curr Med Sci 2018;38:26-34.

54. Yen TT, Yang A, Chiu WT, Li TN, Wang LH, et al. Hepatitis B virus PreS2-mutant large surface antigen activates store-operated calcium entry and promotes chromosome instability. Oncotarget 2016;7:23346-60.

55. Zhang Z, Chen J, He Y, Zhan X, Zhao R, et al. miR-125b inhibits hepatitis B virus expression in vitro through targeting of the SCNN1A gene. Arch Virol 2014;159:3335-43.

56. Taylor JM, Han Z. Purinergic receptor functionality is necessary for infection of human hepatocytes by hepatitis delta virus and hepatitis B virus. PloS One 2010;5:e15784.

57. Wirth TC, Manns MP. The impact of the revolution in hepatitis C treatment on hepatocellular carcinoma. Ann Oncol 2016;27:1467-74.

58. Jahan S, Ashfaq UA, Qasim M, Khaliq S, Saleem MJ, et al. Hepatitis C virus to hepatocellular carcinoma. Infect Agent Cancer 2012;7:2.

59. Griffin SD, Beales LP, Clarke DS, Worsfold O, Evans SD, et al. The p7 protein of hepatitis C virus forms an ion channel that is blocked by the antiviral drug, Amantadine. FEBS Lett 2003;535:34-8. 
60. Chandler DE, Penin F, Schulten K, Chipot C. The p7 protein of hepatitis C virus forms structurally plastic, minimalist ion channels. PLoS Comput Biol 2012;8:e1002702.

61. Foster TL, Verow M, Wozniak AL, Bentham MJ, Thompson J, et al. Resistance mutations define specific antiviral effects for inhibitors of the hepatitis C virus p7 ion channel. Hepatology 2011;54:79-90.

62. Jones CT, Murray CL, Eastman DK, Tassello J, Rice CM. Hepatitis C virus p7 and NS2 proteins are essential for production of infectious virus. J Virol 2007;81:8374-83.

63. Steinmann E, Penin F, Kallis S, Patel AH, Bartenschlager R, et al. Hepatitis C virus p7 protein is crucial for assembly and release of infectious virions. PLoS Pathog 2007;3:e103.

64. Wozniak AL, Griffin S, Rowlands D, Harris M, Yi M, et al. Intracellular proton conductance of the hepatitis C virus p7 protein and its contribution to infectious virus production. PLoS Pathog 2010;6:e1001087.

65. Griffin S, Stgelais C, Owsianka AM, Patel AH, Rowlands D, et al. Genotype-dependent sensitivity of hepatitis C virus to inhibitors of the p7 ion channel. Hepatology 2008;48:1779-90.

66. Steinmann E, Whitfield T, Kallis S, Dwek RA, Zitzmann N, et al. Antiviral effects of amantadine and iminosugar derivatives against hepatitis C virus. Hepatology 2007;46:330-8.

67. Shiryaev VA, Radchenko EV, Palyulin VA, Zefirov NS, Bormotov NI, et al. Molecular design, synthesis and biological evaluation of cage compound-based inhibitors of hepatitis C virus p7 ion channels. Eur J Med Chem 2018;158:214-35.

68. Pietschmann T. Clinically approved ion channel inhibitors close gates for hepatitis $\mathrm{C}$ virus and open doors for drug repurposing in infectious viral diseases. J Virol 2017;91.

69. Breitinger U, Farag NS, Ali NKM, Breitinger HA. Patch-clamp study of hepatitis C p7 channels reveals genotype-specific sensitivity to inhibitors. Biophy J 2016;110:2419-29.

70. Hong W, Lang Y, Li T, Zeng Z, Song Y, et al. A p7 ion channel-derived peptide inhibits hepatitis C virus infection in vitro. J Biol Chem 2015;290:23254-63.

71. Pavlovic D, Neville DC, Argaud O, Blumberg B, Dwek RA, et al. The hepatitis C virus p7 protein forms an ion channel that is inhibited by long-alkyl-chain iminosugar derivatives. Proc Natl Acad Sci U S A 2003;100:6104-8.

72. Manzoor S, Idrees M, Ashraf J, Mehmood A, Butt S, et al. Identification of ionotrophic purinergic receptors in Huh-7 cells and their response towards structural proteins of HCV genotype 3a. Virol J 2011;8:431.

73. Manzoor S, Akhtar U, Naseem S, Khalid M, Mazhar M, et al. Ionotropic purinergic receptors P2X4 and P2X7: proviral or antiviral? An insight into P2X receptor signaling and hepatitis C virus infection. Viral Immunol 2016;29:401-8.

74. Sidorkiewicz M, Brocka M, Bronis M, Grek M, Jozwiak B, et al. The altered expression of alpha1 and beta3 subunits of the gammaaminobutyric acid A receptor is related to the hepatitis C virus infection. Eur J Clin Microbiol Infect Dis 2012;31:1537-42.

75. Streba LA, Vere CC, Rogoveanu I, Streba CT. Nonalcoholic fatty liver disease, metabolic risk factors, and hepatocellular carcinoma: an open question. World J Gastroenterol 2015;21:4103-10.

76. Kikuchi L, Oliveira CP, Carrilho FJ. Nonalcoholic fatty liver disease and hepatocellular carcinoma. Biomed Res Int 2014;2014:106247.

77. Dhamija E, Paul SB, Kedia S. Non-alcoholic fatty liver disease associated with hepatocellular carcinoma: an increasing concern. Indian J Med Res 2019;149:9-17.

78. Wulff $\mathrm{H}$, Castle NA. Therapeutic potential of KCa3.1 blockers: recent advances and promising trends. Expert Rev Clin Pharmacol 2010;3:385-96.

79. Freise C, Heldwein S, Erben U, Hoyer J, Kohler R, et al. $\mathrm{K}^{+}$-channel inhibition reduces portal perfusion pressure in fibrotic rats and fibrosis associated characteristics of hepatic stellate cells. Liver Int 2015;35:1244-52.

80. Paka L, Smith DE, Jung D, McCormack S, Zhou P, et al. Anti-steatotic and anti-fibrotic effects of the KCa3.1 channel inhibitor, Senicapoc, in non-alcoholic liver disease. World J Gastroenterol 2017;23:4181-90.

81. Blasetti Fantauzzi C, Menini S, Iacobini C, Rossi C, Santini E, et al. Deficiency of the purinergic receptor $2 X 7$ attenuates nonalcoholic steatohepatitis induced by high-fat diet: possible role of the NLRP3 inflammasome. Oxid Med Cell Longev 2017;2017:8962458.

82. Shang Y, Li XF, Jin MJ, Li Y, Wu YL, et al. Leucodin attenuates inflammatory response in macrophages and lipid accumulation in steatotic hepatocytes via P2x7 receptor pathway: a potential role in alcoholic liver disease. Biomed Pharmacother 2018;107:374-81.

83. Huang C, Yu W, Cui H, Wang Y, Zhang L, et al. P2X7 blockade attenuates mouse liver fibrosis. Mol Med Rep 2014;9:57-62.

84. Wilson CH, Ali ES, Scrimgeour N, Martin AM, Hua J, et al. Steatosis inhibits liver cell store-operated $\mathrm{Ca}^{2+}$ entry and reduces $\mathrm{ER} \mathrm{Ca}^{2+}$ through a protein kinase C-dependent mechanism. Biochem J 2015;466:379-90.

85. Grimm C, Holdt LM, Chen CC, Hassan S, Muller C, et al. High susceptibility to fatty liver disease in two-pore channel 2-deficient mice. Nat Commun 2014;5:4699.

86. Li Q, Li L, Wang F, Chen J, Zhao Y, et al. Dietary capsaicin prevents nonalcoholic fatty liver disease through transient receptor potential vanilloid 1-mediated peroxisome proliferator-activated receptor delta activation. Pflugers Arch 2013;465:1303-16.

87. Li L, Chen J, Ni Y, Feng X, Zhao Z, et al. TRPV1 activation prevents nonalcoholic fatty liver through UCP2 upregulation in mice. Pflugers Arch 2012;463:727-32.

88. Zhan L, Li J. The role of TRPV4 in fibrosis. Gene 2018;642:1-8.

89. Iyer SC, Kannan A, Gopal A, Devaraj N, Halagowder D. Receptor channel TRPC6 orchestrate the activation of human hepatic stellate cell under hypoxia condition. Exp Cell Res 2015;336:66-75.

90. Fang L, Zhan S, Huang C, Cheng X, Lv X, et al. TRPM7 channel regulates PDGF-BB-induced proliferation of hepatic stellate cells via PI3K and ERK pathways. Toxicol Appl Pharmacol 2013;272:713-25.

91. Pan CX, Wu FR, Wang XY, Tang J, Gao WF, et al. Inhibition of ASICs reduces rat hepatic stellate cells activity and liver fibrosis: an in 
vitro and in vivo study. Cell Biol Int 2014;38:1003-12.

92. Starr SP, Raines D. Cirrhosis: diagnosis, management, and prevention. Am Fam Physician 2011;84:1353-9.

93. Tsochatzis EA, Bosch J, Burroughs AK. Liver cirrhosis. Lancet 2014;383:1749-61.

94. Romanelli RG, Stasi C. Recent advancements in diagnosis and therapy of liver cirrhosis. Curr Drug Targets 2016;17:1804-17.

95. Liu G, Xie C, Sun F, Xu X, Yang Y, et al. Clinical significance of transient receptor potential vanilloid 2 expression in human hepatocellular carcinoma. Cancer Genet Cytogenet 2010;197:54-9.

96. Zúñiga-García V, Chávez-López Mde G, Quintanar-Jurado V, Gabiño-López NB, Hernández-Gallegos E, et al. Differential expression of ion channels and transporters during hepatocellular carcinoma development. Dig Dis Sci 2015;60:2373-83.

97. Dufour JF, Luthi M, Forestier M, Magnino F. Expression of inositol 1,4,5-trisphosphate receptor isoforms in rat cirrhosis. Hepatology 1999;30:1018-26.

98. Xian ZH, Cong WM, Wang YH, Wang B, Wu MC. Expression and localization of aquaporin-1 in human cirrhotic liver. Pathol Res Pract 2009;205:774-80.

99. Yokomori H, Oda M, Yoshimura K, Kaneko F, Hibi T. Aquaporin-1 associated with hepatic arterial capillary proliferation on hepatic sinusoid in human cirrhotic liver. Liver Int 2011;31:1554-64.

100. Fabrega E, Berja A, Garcia-Unzueta MT, Guerra-Ruiz A, Cobo M, et al. Influence of aquaporin-1 gene polymorphism on water retention in liver cirrhosis. Scand J Gastroenterol 2011;46:1267-74.

101. Rodríguez-Vilarrupla A, Graupera M, Matei V, Bataller R, Abraldes JG, et al. Large-conductance calcium-activated potassium channels modulate vascular tone in experimental cirrhosis. Liver Int 2008;28:566-73.

102. Yu Z, Serra A, Sauter D, Loffing J, Ackermann D, et al. Sodium retention in rats with liver cirrhosis is associated with increased renal abundance of $\mathrm{NaCl}$ cotransporter (NCC). Nephrol Dial Transplant 2005;20:1833-41.

103. Yang XW, Liu JW, Zhang RC, Yin Q, Shen WZ, et al. Inhibitory effects of blockage of intermediate conductance $\mathrm{Ca}^{2+}$-activated $\mathrm{K}^{+}$ channels on proliferation of hepatocellular carcinoma cells. J Huazhong Univ Sci Technolog Med Sci 2013;33:86-89.

104. Freise C, Ruehl M, Seehofer D, Hoyer J, Somasundaram R. The inhibitor of $\mathrm{Ca}^{2+}$-dependent $\mathrm{K}^{+}$channels TRAM-34 blocks growth of hepatocellular carcinoma cells via downregulation of estrogen receptor alpha mRNA and nuclear factor-kappaB. Invest New Drugs 2013;31:452-7.

105. Fan H, Zhang M, Liu W. Hypermethylated KCNQ1 acts as a tumor suppressor in hepatocellular carcinoma. Biochem Biophys Res Commun 2018;503:3100-7.

106. Zhang K, Mu L, Ding MC, Xu R, Ding ZJ, et al. NFkappaB mediated elevation of KCNJ11 promotes tumor progression of hepatocellular carcinoma through interaction of lactate dehydrogenase A. Biochem Biophys Res Commun 2018;495:246-53.

107. Pardo LA, Stuhmer W. Eag1: an emerging oncological target. Cancer Res 2008;68:1611-3.

108. Wulff H, Castle NA, Pardo LA. Voltage-gated potassium channels as therapeutic targets. Nat Rev Drug Discov 2009;8:982-1001.

109. Pardo LA, del Camino D, Sanchez A, Alves F, Bruggemann A, et al. Oncogenic potential of EAG K ${ }^{+}$channels. EMBO J 1999;18:5540-7.

110. Rodríguez-Rasgado JA, Acuña-Macías I, Camacho J. Eag1 channels as potential cancer biomarkers. Sensors (Basel) 2012;12:5986-95.

111. Farias LM, Ocana DB, Diaz L, Larrea F, Avila-Chavez E, et al. Ether a go-go potassium channels as human cervical cancer markers. Cancer Res 2004;64:6996-7001.

112. Gómez-Varela D, Zwick-Wallasch E, Knötgen H, Sánchez A, Hettmann T, et al. Monoclonal antibody blockade of the human Eag1 potassium channel function exerts antitumor activity. Cancer Res 2007;67:7343-9.

113. García-Becerra R, Díaz L, Camacho J, Barrera D, Ordaz-Rosado D, et al. Calcitriol inhibits Ether-a go-go potassium channel expression and cell proliferation in human breast cancer cells. Exp Cell Res 2010;316:433-42.

114. Weber C, Mello de Queiroz F, Downie BR, Suckow A, Stuhmer W, et al. Silencing the activity and proliferative properties of the human EagI Potassium Channel by RNA Interference. J Biol Chem 2006;281:13030-7.

115. de Guadalupe Chávez-López M, Pérez-Carreón JI, Zuñiga-García V, Díaz-Chávez J, Herrera LA, et al. Astemizole-based anticancer therapy for hepatocellular carcinoma (HCC), and Eag1 channels as potential early-stage markers of HCC. Tumour Biol 2015;36:6149-58.

116. Dziegielewska B, Gray LS, Dziegielewski J. T-type calcium channels blockers as new tools in cancer therapies. Pflugers Arch 2014;466:801-10.

117. Li Y, Liu S, Lu F, Zhang T, Chen H, et al. A role of functional T-type $\mathrm{Ca}^{2+}$ channel in hepatocellular carcinoma cell proliferation. Oncol Rep 2009;22:1229-35.

118. Xie R, Xu J, Wen G, Jin H, Liu X, et al. The P2Y2 nucleotide receptor mediates the proliferation and migration of human hepatocellular carcinoma cells induced by ATP. J Biol Chem 2014;289:19137-49.

119. Maynard JP, Lee JS, Sohn BH, Yu X, Lopez-Terrada D, et al. P2X3 purinergic receptor overexpression is associated with poor recurrencefree survival in hepatocellular carcinoma patients. Oncotarget 2015;6:41162-79.

120. Yang N, Tang Y, Wang F, Zhang H, Xu D, et al. Blockade of store-operated $\mathrm{Ca}^{2+}$ entry inhibits hepatocarcinoma cell migration and invasion by regulating focal adhesion turnover. Cancer Lett 2013;330:163-9.

121. Tang BD, Xia X, Lv XF, Yu BX, Yuan JN, et al. Inhibition of Orail-mediated $\mathrm{Ca}^{2+}$ entry enhances chemosensitivity of HepG2 hepatocarcinoma cells to 5-fluorouracil. J Cell Mol Med 2017;21:904-15.

122. Wang R, Kang B, Hu R, Huang Y, Qin Z, et al. ClC-3 chloride channel protein induces G1 arrest in hepatocellular carcinoma Hep3B cells. Oncol Rep 2018;40:472-8.

123. Wei X, Li J, Xie H, Wang H, Wang J, et al. Chloride intracellular channel 1 participates in migration and invasion of hepatocellular carcinoma by targeting maspin. J Gastroenterol Hepatol 2015;30:208-16.

124. Guo G, Cui Y, Chen H, Zhang L, Zhao M, et al. Analgesic-antitumor peptide inhibits the migration and invasion of HepG2 cells by an 
upregulated VGSC beta1 subunit. Tumour Biol 2016;37:3033-41.

125. He Z, Dong W, Hu J, Ren X. AQP5 promotes hepatocellular carcinoma metastasis via NF-kappaB-regulated epithelial-mesenchymal transition. Biochem Biophy Res Commun 2017;490:343-8.

126. Zhang Z, Han Y, Sun G, Liu X, Jia X, et al. MicroRNA-325-3p inhibits cell proliferation and induces apoptosis in hepatitis B virusrelated hepatocellular carcinoma by down-regulation of aquaporin 5. Cell Mol Biol Lett 2019;24:13.

127. Li CF, Zhang WG, Liu M, Qiu LW, Chen XF, et al. Aquaporin 9 inhibits hepatocellular carcinoma through up-regulating FOXO1 expression. Oncotarget 2016;7:44161-70.

128. Zhang WG, Li CF, Liu M, Chen XF, Shuai K, et al. Aquaporin 9 is down-regulated in hepatocellular carcinoma and its over-expression suppresses hepatoma cell invasion through inhibiting epithelial-to-mesenchymal transition. Cancer Lett 2016;378:111-9.

129. Xu J, Yang Y, Xie R, Liu J, Nie X, et al. The NCX1/TRPC6 complex mediates TGFbeta-driven migration and invasion of human hepatocellular carcinoma cells. Cancer Res 2018;78:2564-76.

130. Tian Y, Zhu MX. A novel TRPC6-dependent mechanism of TGF-beta-induced migration and invasion of human hepatocellular carcinoma cells. Sci China Life Sci 2018;61:1120-2.

131. Wen L, Liang C, Chen E, Chen W, Liang F, et al. Regulation of multi-drug resistance in hepatocellular carcinoma cells is TRPC6/calcium dependent. Sci Rep 2016;6:23269.

132. Selli C, Erac Y, Kosova B, Erdal ES, Tosun M. Silencing of TRPC1 regulates store-operated calcium entry and proliferation in Huh7 hepatocellular carcinoma cells. Biomed Pharmacother 2015;71:194-200.

133. Selli C, Pearce DA, Sims AH, Tosun M. Differential expression of store-operated calcium- and proliferation-related genes in hepatocellular carcinoma cells following TRPC1 ion channel silencing. Mol Cell Biochem 2016;420:129-40.

134. Miao X, Liu G, Xu X, Xie C, Sun F, et al. High expression of vanilloid receptor-1 is associated with better prognosis of patients with hepatocellular carcinoma. Cancer Genet Cytogenet 2008;186:25-32.

135. Chen WT, Lin GB, Lin SH, Lu CH, Hsieh CH, et al. Static magnetic field enhances the anticancer efficacy of capsaicin on HepG2 cells via capsaicin receptor TRPV1. PloS One 2018;13:e0191078.

136. Hu Z, Cao X, Fang Y, Liu G, Xie C, et al. Transient receptor potential vanilloid-type 2 targeting on stemness in liver cancer. Biomed Pharmacother 2018;105:697-706.

137. Fang Y, Liu G, Xie C, Qian K, Lei X, et al. Pharmacological inhibition of TRPV4 channel suppresses malignant biological behavior of hepatocellular carcinoma via modulation of ERK signaling pathway. Biomed Pharmacother 2018;101:910-9.

138. Chen Y, Yu Y, Sun S, Wang Z, Liu P, et al. Bradykinin promotes migration and invasion of hepatocellular carcinoma cells through TRPM7 and MMP2. Exp Cell Res 2016;349:68-76.

139. Jin C, Ye QH, Yuan FL, Gu YL, Li JP, et al. Involvement of acid-sensing ion channel 1alpha in hepatic carcinoma cell migration and invasion. Tumour Biol 2015;36:4309-17.

140. Pittala S, Krelin Y, Shoshan-Barmatz V. Targeting liver cancer and associated pathologies in mice with a mitochondrial VDAC1-based peptide. Neoplasia 2018;20:594-609.

141. Guerra MT, Florentino RM, Franca A, Lima Filho AC, Dos Santos ML, et al. Expression of the type 3 InsP3 receptor is a final common event in the development of hepatocellular carcinoma. Gut 2019;68:1676-87.

142. Hartke J, Johnson M, Ghabril M. The diagnosis and treatment of hepatocellular carcinoma. Semin Diagn Pathol 2017;34:153-9.

143. Stühmer W, Alves F, Hartung, F, Zientkowska M, Pardo LA. Potassium channels as tumour markers. FEBS Lett 2006;580:2850-2.

144. Black JA, Waxman SG. Noncanonical roles of voltage-gated sodium channels. Neuron 2013;80:280-91.

145. Downie BR, Sánchez A, Knötgen H, Contreras-Jurado C, Gymnopoulos M, et al. Eag1 expression interferes with hypoxia homeostasis and induces angiogenesis in tumors. J Biol Chem 2008;283:36234-40.

146. Buchanan PJ, McCloskey KD. $\mathrm{Ca}_{\mathrm{V}}$ channels and cancer: canonical functions indicate benefits of repurposed drugs as cancer therapeutics. Eur Biophys J 2016;45:621-33.

147. Lee H, Kang S, Kim W. Drug repositioning for cancer therapy based on large-scale drug-induced transcriptional signatures. PloS One 2016;11:e0150460.

148. Ellegaard AM, Dehlendorff C, Vind AC, Anand A, Cederkvist L, et al. Repurposing cationic amphiphilic antihistamines for cancer treatment. EBioMedicine 2016;9:130-9. 